\title{
CELEBRATION AND CONFRONTATION: YUSEF KOMUNYAKAA IN CONVERSATION ABOUT WALT WHITMAN
}

YUSEF KomunyakaA is the author of fourteen volumes of poetry, including the Pulitzer Prize-winning 1994 collection Neon Vernacular. His many other honors include the Kingsley Tufts Poetry Award, the Ruth Lilly Poetry Prize, and the Wallace Stevens Award. His most recent book, The Chameleon Couch (2011) was a finalist for the National Book Award. He is Global Distinguished Professor of English at New York University. The absorptive, kaleidoscopic range of Komunyakaa's verse has led some reviewers to draw parallels between his work and Whitman's-a comparison Komunyakaa has modestly described as "an easy-less than critical-gesture." However, while he may not be a "Whitmanesque" poet, Komunyakaa has long displayed a keen interest in Whitman's work, as manifested in the allusions contained within poems such as "Kosmos" (1992), "The Poetics of Paperwood" (1992), and "Praise Be" (2005), as well as references to Whitman that the poet has made in interviews, and his participation in the $2008 \mathrm{PBS}$ documentary American Experience: Walt Whitman. At least one parallel between the two writers is worth preserving: both defy easy generalization. For example, Komunyakaa's work often explores the meanings of black experience. Yet race, unquestionably one of the major themes of his poetry, is not a connective thread holding all of it together. Rather, if there is a perpetual theme in Komunyakaa's work, it is the startling diversity that exists within both his own-and the collective-imagination. Whitman's lines from "Whoever You Are Holding Me Now in Hand" are a fitting description of Komunyakaa's protean verse, always disclosing the unexpected:

Even while you should think you had unquestionably caught me, behold! Already you see I have escaped from you. ${ }^{2}$

The interview that follows was conducted in New York in August 2010. 
Facob Wilkenfeld: What first drew you to Whitman? What were the most significant aspects for you of your first readings of Leaves of Grass?

Yusef Komunyakaa: I was in high school when I first came across Whitman's name. And at the time I was reading poetry from the Harlem Renaissance. Before that, I had been reading poems such as Tennyson's "The Eagle," James Weldon Johnson's "The Creation," and Paul Laurence Dunbar's "The Colored Soldiers." I went to check out Whitman's poems from the school library, but the volume wasn't on the shelf. The librarian had been instructed to keep Whitman behind the circulation desk. Yet, somehow, I actually checked out the volume. Of course, it was different from Tennyson. It was also different from the Harlem Renaissance poets (their protest sonnets), and it was definitely different from Poe ("Annabel Lee"). I became immediately caught up in Whitman's language. In retrospect, what was instructive to me was the music in his poetry. And much later, decades later, I found myself reading him again, and it was almost like reading the volume for the first time-Leaves of Grass. But I think my body remembers the music more than my mind remembers the music. There was urgency, an experience underneath the language that surprised me. And his imagination was so huge. That was the thing. His imagination was almost otherworldly at times, but also seemed naturally insightful and encompassing. His references on democracy were interesting, because I had never heard anyone speak so passionately about democracy except possibly James Baldwin, whom I discovered at fourteen. And Baldwin, of course, was constantly talking about the possibility of democracy and of the responsibility to ideas of freedom. I think Whitman, in a certain sense, speaks about responsibility, responsibility through, first, the imagination - that one has to imagine another person free before he or she can even see that person, feel that person in a moment of shared freedom.

$\mathcal{F W}$ : In the recent PBS American Experience program on Whitman, you single out the auction block scene in "I Sing the Body Electric" as an example of Whitmanian empathetic identification with others, regardless of their cultural origins. In your words, "For some reason I feel like he has the capacity to imagine himself on the auction block as well . . . I It really enters his psyche. I think he's wrestling with himself." ${ }_{3}$ Could you speak some more about this dimension of Whitman's work and its significance for you?

$Y K$ : This idea of being empathetic is also embedded in the idea of democracy. For Whitman, it is not an abstraction. His seems really intense empathy. I think what he basically believed is that one is not really human until he possesses the capacity of empathy through the imagi- 
nation. Also, there are so many references to the body, as if language enters the body and becomes tactile and physical. So when Whitman speaks of the black man, such as the passage where he sees this black man driving a horse-drawn wagon, he seems to be sitting there beside him. He is not, at that moment, merely of compressed belief and passion. In the woven language of the poem, Whitman may even be that man. I think this is really an amazing kind of epiphany. Likewise, for this poet, the auction block seems more than a physical dimension: a part of his psyche. He's a witness.

$\mathcal{F W}$ : In another interview, you have said that Whitman's vision, like Langston Hughes's, is "driven by an acute sense of beauty and tragedy in America's history." This also seems an apt description of your writing. Like Whitman, you have written very profoundly about the tragedies of war but also about other forms of American tragedy. Could you talk about the interrelationship between beauty and tragedy in your poetry and in Whitman's?

$Y K$ : Perhaps I borrowed the phrase from another phrase of mine, as it relates to nature, that there always seems to be an alignment of beauty and terror. Whitman doesn't back off from that which is beautiful. He celebrates it. Nor does he back off from tragedy. Death-he's right there, almost on the deathbed. And it is so tactile. It is so physical. At times, however, Whitman risks sentimentality. We can define sentimentality as passion without form, basically. But at the same time, Whitman can write about a mockingbird, almost as if this mockingbird has symphonic capacity, and I admire that, because he is also listening very carefully. In Leaves of Grass, that's the idea. The title relates to the simple beauty of nature, and then the pages morph into human complexity. One leaf is different from all the other leaves, and that multitude is always crowding Whitman's brain. So beauty is severe. Sometimes beauty is as severe as tragedy, and there is a marriage between the two in other places in Whitman. One reason is because of the meandering of phrases. Leaves of Grass is a heroic attempt to concretize passion, and I think this is why Whitman influenced so many other poets I associate with a similarly directed passion, such as Neruda or Ginsberg. It's that same kind of earthy feeling. It's almost as if the poet connects directly to the earth. I grew up in a very small town, and my early rituals actually had to do with nature, with celebrating. I was celebrating without even being aware that I was celebrating. Of course, Whitman says in the opening lines of "Song of Myself," "I celebrate myself, / And what I assume you shall assume, / For every atom belonging to me as good belongs to you." And the way he celebrates is acquiring an acute awareness. $\mathrm{He}$ reminds us that it's hard to be aware of nature, its beauty, and not also 
feel a part of it, a respect.

$\mathcal{F W}$ : The critic Kenneth Price has argued that poets of color have a complicated relationship with Whitman. In his words, "There are complex issues involved when an artist of color acknowledges a white predecessor." ${ }^{\circ}$ Do you see this as a valid argument, and why or why not?

$Y K$ : In a way, from an opposite take, we could say that it dehumanizes one who doesn't have the capacity to embrace another. And that is what Whitman is all about in a certain sense. Yet, to embrace the positive elements of Whitman, one has to also be aware of the negative elements. But that's true with each and every human being. Whitman is really a unique product of his own time. He responded to the obvious inequities in our country. The idea of slavery is rather complex, if we really want to get down to the facts. First, one tribe defeats another and sells its prisoners to merchants and ship captains. Now, that's already a complicated situation, right? And we know there are numerous demarcation lines drawn in the dirt, especially when we begin to argue with history, but sometimes we have to be brave enough to cross those lines and demand at least an approximated truth. And we know through inheritance all the old, ugly, pathetic stories of slavery. This is what I feel. Many of us, not only the descendants of former slaves, are constantly defining and redefining who we are as human beings. Whitman was wrestling with himself, because, let's face it, he is a product of that historical moment-a witness. To break off from Whitman for a moment, think of the complexity of a poet such as Phillis Wheatley. One moment she's defending herself before those eighteen Bostonians, and the next moment, in her poetry, she is casting an eye towards Africa that is not sympathetic, saying, "'Twas mercy brought me from my Pagan land ...." There is complexity in that glance, and in history as well.

$\mathcal{F W}$ : In the first version of your poem "Kosmos," you write that Whitman "heard primordial notes of jazz / Murmuring up from the Mississippi."” Do you see Whitman's poetics as analogous to a jazz aesthetic, and, if so, what parallels are there?

$Y K$ : Improvisation. Many of Whitman's poems were improvisational. This doesn't directly parallel elements of passion, but it does parallel the idea of celebration. I think Whitman is really celebrating his voice. He's attempting to celebrate the mystery within himself, and I think that's what the jazz musician does. The jazz musician has a musical phrase or melody that expands, deconstructs musically, and he puts it back together, reconstructs. And I think that's what Whitman is doing. I don't think he's consciously saying, "I'm going to improvise." I don't 
see it as strategy. If anything, his is a voice shaped from need and driven by enthusiastic genius.

$\mathcal{F} W:$ He does have the poem "Spontaneous Me."

$Y K$ : That's right. And if we think about spontaneity, he's already thereahead-alongside the Beats. Spontaneous necessity, spontaneous prose.

$\mathcal{F W}$ : In another interview, you celebrate Whitman for his attention to life rather than abstraction, his inclusiveness, and his willingness to treat aspects of life once considered inappropriate for literature. In your words, Whitman "didn't dodge anything." Do you see today's poets as carrying on this tradition?

$Y K$ : Today's poets? It depends on the poet. As a matter of fact, I think there is a certain amount of erasure in contemporary poetry. And the erasure happens mainly through over-experimentation. This is interesting because Whitman experimented to underscore content. His eyes and ears - his senses caught everything. And some of today's poets-now I don't want everyone writing the same poem. For me as a writer it is important to relate to my experiences, my observations and feelings, to dwell in a place of expansion. And I think that's what Whitman attempted. There are topics that I'm waiting for some young American voices to address. One of them is racism. And how does one address that? The reason I say this is that, just coming back from Paris, I feel like there is more of a racial ease there, people more comfortable with each other. I saw very young people, children of different races, playing together. Not that they had been instructed to play together, but just as what humans do. But at the same time I'm very much aware that there are problems of class among ethnic groups in France, especially when we think of Muslims. Here we tend to sidestep that topic, as if we have already dealt with it. And I suppose the only way to deal with it is on a personal basis, not to have a political agenda, but just as human beings.

$\mathcal{F W}$ : In some ways race is the supreme fiction of American culture.

$Y K$ : Yes, it's an invention. And that invention has kept us apart, but also privileged others. And Whitman, I think, was very much aware of this, this divide that happens. Ironically, I do think that divide is beneficial to some citizens. We don't talk about class either. Recently, I was reading Einstein on Race and Racism, and I was incensed by some of the historical situations described. Einstein attempted to deal with what he witnessed while living in Princeton. He offended some educated people. I think it was Baldwin who, pointing out a difference of the South and North, 
said, in the South the black man is always the subject of discussion, in the North never, so denied in one sense and exaggerated in the other. ${ }^{8}$

$\mathcal{F W}$ : Like Emerson, Whitman views the poet as a representative figure who-differently from but also similarly to a political figure-speaks for a multitude. Do you view the work of the poet in this manner? Also, are there dangers inherent in writers' presuming to identify with or speak on behalf of others? And are there dangers in poetic attempts at inclusiveness?

$Y K$ : I think it is necessary in the twenty-first century. We have to think of when Whitman was writing. I think he was taking a risk. Now, there is a certain white poet, a contemporary of mine, who says that he writes for white people. I think that is so narrow-minded it's laughable and tragic - not necessarily for others so much as tragic for him. I believe we have the capacity, and one has to say the audacity, to carry each other in our hearts, in our minds as well, and write for anyone who dares to pick up our work, but first write for oneself.

$\mathcal{F W}$ : Some have argued that instead of letting different voices speak through him, Whitman imposes his poetic persona upon others. Critics have argued that his poetry is not truly multiperspectival.

$Y K$ : Whitman's definitely egotistical, and I think he had to be at that particular time to assume the voice of the great poet. We can see and feel him inventing himself. Is this the same thing that happened with Dante? Perhaps so. I think Whitman was taken by his singing. That's the way I see Whitman, as a singer, more than as the solitary poet sitting in a corner, going from phrase to phrase. I'm willing to bet Whitman read everything aloud as he was composing. I bet he was having great fun. He talks about dancing as well. He makes language dance. And in dance we think of celebration. Often, poets confront certain things and celebrate other things. But sometimes a single line is a moment of celebration and the next line is a moment of stern, necessary confrontation. Sometimes it's a confrontation with oneself, not necessarily with the external world. There's an insinuation, suggesting that we don't have to have an argument with what's around us, but we can definitely have an argument with what we are made of.

$\mathcal{F W}$ : You have also alluded to some of the more troubling aspects of Whitman's poetic project. You have spoken of fetishism or the eroticizing of characters in his work. You also touch on this dimension of Whitman's work in the second version of your poem "Kosmos," when you address Whitman as "locked inside / your exotic Ethiopia." Could 
$Y K$ : Whitman's poems are very sexual. He was a sexual being. There's muscle inside his imagination. His lines. My belief is that Whitman also reacted to the general feeling embedded in the national psyche about blacks. Whitman definitely encountered that. How could he not? The slave on the auction block is always stripped down. Even the black man driving the coach is very physical through depiction. Whitman draws him with robust energy. That became very much a part of Whitman's psyche. It's interesting, because that is something that we, contemporary poets, celebrate as well. And sometimes, if we think of time and space, it is in just a glance. I think Whitman was trying to be truthful to himself, but at the same time, in fetishizing, there's a risk involved, to make that other human being into an object. I don't care if it's an object of adoration. It's still an object, and we're all capable of that to an extent. How can we not be? Because we're using the tools of language-symbols embedded in language. Poets have always existed in a visual culture, even if it occurs mainly in the head, through tonal imagery. And some of the definitions of those symbols carry all kinds of connotation, innuendo, insinuation, and it's hard to be outside of that. So I hold Whitman accountable as I hold myself accountable.

$\mathcal{F W}$ : Michael Baxandall has made a strong case for the misguidedness of critical approaches that look at influence in a traditional way. ${ }^{10}$ In his view, critics should look more at what the second artist does to his/ her precursor, rather than at how the precursor has affected the later artist. In this sense, is it proper to speak of a Whitmanian influence on your poetry, or is there a better way to describe your engagement with Whitman's work?

$Y K$ : In a certain sense, when I first read Whitman I didn't think of a great distance. I heard an echo of a voice coming to me that was really a composite of other voices I had grown up with. And in that sense, when I started writing poetry, I don't think I had Whitman's voice in my head as much as I had the voices of others in my head, though I had read Whitman. I had read Tennyson. I had read the Harlem Renaissance poets. I think that what happened is that Whitman gave me a deeper hearing, which may be in concert with a deeper singing. Because I think it's all about listening. And sometimes if we have, even accidentally, listened, we can hear an echo of the singing. I don't think that Whitman really sets out to make sense of the world. However, we participate as listeners and readers, to make sense of Whitman. And in that sense, we are making sense of Whitman's world. Maybe what's 
most constructive, for me, is to continue to believe that there's mystery. Whitman I think taught me to accept mystery. Everything doesn't have to be explained. Everything doesn't have to equal a neat number. But there is this immense mystery.

$\mathcal{F W}$ : He says "I and this mystery here we stand."

$Y K$ : Here we stand. Yeah. I don't know if I answered your question, but I'm going to come back to it in a different way. I think the artist is always more directly influenced by what he or she isn't conscious of. If one purposely sets out to imitate another artist, there's a real problem. It's important to have a foundation and then to go through that, embrace that foundation, and go where one's imagination, one's experiences, one's passions can take him or her.

$\mathcal{F W}$ : Can we speak of a Whitmanian tradition, and if so, which contemporary poets do you see as belonging to it?

$Y K$ : Of course we could say, off the top of the head, Galway Kinnell, Phillip Levine, C.K. Williams, Gerald Stern, Allen Ginsberg. I know you're waiting for black poets. [Laughs.] No, I'm kidding. Michael Harper. Gwendolyn Brooks. But we can even say a voice such as Baraka.

$\mathcal{F} W$ : I would wonder what he would say about that.

$Y K$ : I wonder what he would say about that. [Laughs.] But also I think of Robert Hayden, especially some of the longer poems. "Middle Passage" comes to mind. Even someone like Jay Wright, his "The Cradle Logic of Autumn" possesses an echo of Whitman.

$\mathcal{F W}$ : Martín Espada has described himself as "a branch on the tree of Whitman." 12

$Y K$ : Yes, Martín Espada does exhibit a similar facility for language and raw passion. The music - the rhetorical drive, the celebration, the common man and woman, it's all there in Martín's voice.

FW: In "The Poet," a lecture that had a profound influence on Whitman, Emerson exhorts prospective American writers to perceive, "in the barbarism and materialism of the times, another carnival of the same gods whose picture he so much admires in Homer."'13 Your own work, particularly your more recent verse, suggests the relevance of ancient narratives to contemporary life. Could you speak about the interplay you 
see between ancient narratives — both historical and mythological—and modern-day experience and poetry?

$Y K$ : I think I'm paying allegiance to the human brain, that fluid mechanism that exists by creating syntactic links-leaps. I'm thinking of all the things I've read, all the things I've experienced, all the things I've thought of. I don't think the brain attempts to create strict categories. Things collide and time dissolves. The old brain and the new brain are no more than a jump cut apart. Perhaps this has a lot to do with creating a poetic time, where the mythological, the present moment, even the future, all can live in the same moment of feeling and reckoning. I think Whitman talks about that, attempts to bring the future into the present.

\section{$\mathcal{F W}$ : As in "Crossing Brooklyn Ferry."}

$Y K$ : Yes. Although this is essentially a cityscape, Whitman is the unrelenting spirit of the frontier. He attempts to call together one great force-this huddle of humanity. For me, it's not so much the mythology borrowed from a different time, as that which focuses us on a necessary scrutiny of where we are. There is a certain ancient innuendo in a voice such as Catullus, almost the same kind of insinuation and intensity I see in the blues idiom. And that's a good example of how time is deceived, the idea of time is deceived, changed, redefined. I tend to cross bridges, and sometimes those bridges are in midair, and they sometimes don't necessarily go or travel a predefined direction. And there are some elements of mythology, and classical allusions, that can lead to some interesting, necessary surprises where the sun shines in an alley or on a mountaintop.

$\mathcal{F W}$ : Speaking of Whitman and Dickinson, you have said that "as a poet I embrace Whitman more, with his long lines." ${ }^{14}$ However, your own poetry tends to be composed in shorter lines. Could you speak about the form of Whitman's poetry and any significance it has had for you?

$Y K$ : My poems are usually a composite of short lines. I think that it has something to do with contemporary time, a kind of vertical plunge, with the shorter lines coming out of the Beat movement, reading some of the poets associated with that movement. The long line for me invites more of a meditation, and not that same kind of vertical urgency. Recently, some of my poems seem to have longer lines. I'm particularly thinking of "Blackbirding on the Hudson," and some of my prose poems. Whitman invites a certain meditation with those long lines, and I'm very much interested in that. I remember Richard Hugo saying that a poem 
should have long and short lines. And I think he was talking more about the music, maybe influenced by elements of swing music, the kind of modulation that takes place. I still admire Whitman's long lines because they're almost biblical. And that was really my first introduction to poetry. I suppose that's what happened with Whitman. He takes me back to biblical verse, even though I have probably attempted to forget biblical verse. Maybe that's what it is. It's an echo of that which I first came in contact with.

\section{NOTES}

1 "An Interview with Yusef Komunyakaa, Author of The Chameleon Couch." The Farrar, Straus, and Giroux Poetry Blog (www.fsgpoetry.com).

2 Walt Whitman, Leaves of Grass: Comprehensive Reader's Edition, ed. Harold W. Blodgett and Sculley Bradley (New York: New York University Press, 1965), 116.

3 American Experience: Walt Whitman, directed by Mark Zwonitzer (Boston: PBS/ WGBH, 2008).

4 Yusef Komunyakaa and Radiclani Clytus, Blue Notes: Essays, Interviews, and Commentaries (Ann Arbor: University of Michigan Press, 2000), 31.

5 Kenneth M. Price, To Walt Whitman, America (Chapel Hill: University of North Carolina Press, 2004), 4.

6 Komunyakaa, “Kosmos,” The Massachusetts Review 33 (Spring 1992), 87.

7 Komunyakaa, Conversations with Yusef Komunyakaa, ed. Shirley A. Hanshaw (Jackson: University Press of Mississippi, 2010), 181. Hereafter, Conversations. Originally printed as "A Conversation with Yusef Komunyakaa," conducted by Jeffrey Dodd and Jessica Moll, Willow Spring 56 (2007), 68-79.

8 See Studs Terkel's 1961 interview with Baldwin, in which the former says "In the South, the white man is continuously bringing up the matter of the Negro; in the north, never. So obsessed in one case, so ignored in the other." In Fred L. Standley and Louis H. Pratt, Conversations with Fames Baldwin (Jackson: University Press of Mississippi, 1989), 8.

9 Komunyakaa, Pleasure Dome: New and Selected Poems (Hanover, NH: Wesleyan University Press, 1998), 13.

10 In Baxandall's words, “'Influence' is a curse of art criticism primarily because of its wrong-headed grammatical prejudice about who is the agent and who the patient: it seems to reverse the active/passive relation which the historical actor experiences and the inferential beholder will wish to take into account. If one says that $\mathrm{X}$ influenced $\mathrm{Y}$ it does seem that one is saying that $\mathrm{X}$ did something to $\mathrm{Y}$ rather than that $\mathrm{Y}$ did something to $\mathrm{X}$. But in the consideration of good pictures and painters the second is always the more lively reality. ... Most of these relations just cannot be stated the other way round-in terms of $\mathrm{X}$ acting on $\mathrm{Y}$ rather than $\mathrm{Y}$ acting on $\mathrm{X}$. To think in terms of influence blunts thought by impoverishing the means of differentiation." Michael Baxandall, Patterns of Intention: On the Historical Explanation of Pictures (New Haven: Yale University Press, 1985), 58-59. 
11 Whitman, Leaves of Grass (Brooklyn: 1855), 14. Available on the Walt Whitman Archive (whitmanarchive.org).

12 Edward Carvalho, "A Branch on the Tree of Whitman: Martín Espada Talks about Leaves of Grass," Walt Whitman Quarterly Review 26 (Summer 2008), 25.

13 Ralph Waldo Emerson, Essays: First and Second Series (New York: Library of America, 1990), 465.

14 Komunyakaa, Conversations, 184. 